\title{
Civic Dignity as the Basis for Public Participation in the Legislative Process
}

\author{
Barbara E. Loots*
}

The Constitution of the Republic of South Africa places an obligation on both Houses of Parliament to facilitate public participation in their legislative processes. The Constitutional Court held in the Doctors for Life judgment that this is a legally enforceable obligation and that a failure to comply with it must result in the invalidity of the said legislation. In the Court's view, the Constitution embraces a rich understanding of democracy which encompasses both representative and participatory elements. In this chapter, I examine the understanding of democracy underlying this judgment, with reference to the notion of civic dignity, as relied on by the Court. I also critically analyse subsequent judgments of the Constitutional Court in which the link between public participation and civic dignity was under-emphasised. These cases created the impression that the Court, rather than carefully engaging with the particular context of every case, more readily deferred to the decisions of Parliament.

\section{A. Introduction}

The Constitution of the Republic of South Africa, 1996 places an obligation on both Houses of Parliament ${ }^{1}$ to facilitate public involvement in their

* I would like to thank Prof H Botha for his invaluable comments and guidance in the drafting of this chapter. The critical analyses reflected herein are based on my own reading of the referenced cases and materials. The primary focus falls on judicial understandings of 'civic dignity' and 'public participation', and the chapter is not intended as a commentary on parliamentary programmes relating to public participation.

1 The two jointly administered Houses are the National Assembly (elected by the voters through their support of a specific political party) and the National Council of Provinces (representing the provinces to ensure that the interests of provinces are considered in the national sphere of government). Hereafter respectively referred to 
processes. ${ }^{2}$ The Constitution thus accords considerable importance to active citizen participation in the law-making process. In the landmark judgment of Doctors for Life International v Speaker of the National Assembly and Others, ${ }^{3}$ the Constitutional Court held that non-compliance with this requirement must result in the invalidity of the legislation in question. If those governed by laws are not granted a reasonable opportunity to be involved in the legislative process, the resulting legislation cannot bind them. ${ }^{4}$

The judgment in Doctors for Life raises fundamental issues about the relationship between representative and participatory democracy. It also raises questions about the relationship between democracy and other constitutional values. The majority of the Court linked democracy to dignity and relied in part on the notion of civic dignity to support its participatory vision of democracy. ${ }^{5}$ Democracy, on this view, presupposes respect for the people and requires their views to be considered in the law-making process. All citizens are entitled to equal recognition - accordingly, all citizens should be afforded an opportunity to participate in the legislative process.

In this chapter, I start by setting out the main reasons for the majority judgment in Doctors for Life. I also compare the majority and minority judgments. Next, I examine the nature of the Court's views on the relation between representative and participatory democracy, and between democracy and the equal dignity of citizens. I then turn to a consideration of cases decided after Doctors for Life. I conclude with tentative observations on the possibilities and limits of the Constitutional Court's dignity-based understanding of participatory democracy.

as the 'NA' and 'NCOP'. See Parliament of the RSA, How Parliament Is Structured, http://www.parliament.gov.za (last accessed on 12 March 2015).

2 Sections 59 and 72 of the Constitution of the Republic of South Africa, 1996, relating to the NA and NCOP respectively. See also s 118 in relation to public involvement in the provincial legislatures.

32006 (12) BCLR 1399 (CC), hereafter 'Doctors for Life'.

4 See Theunis Roux, Democracy in: Stuart Woolman and Michael Bishop (eds.), Constitutional Law of South Africa, Cape Town 2007, ch.10, p. 6; King and Others $v$ Attorneys Fidelity Fund Board of Control and Another 2006 (4) BCLR 462 (SCA), par. 17.

5 See Erin Daly, Dignity Rights: Courts, Constitutions, and the Worth of the Human Person, Philadelphia 2012, p. 132. 


\section{B. The Judgment in Doctors for Life}

The applicants in Doctors for Life approached the Constitutional Court for an order declaring that Parliament had failed to fulfil its constitutional obligation to facilitate public participation in respect of four health related Acts. The majority, in a judgment written by Ngcobo J, ruled that the Constitution imposes an enforceable obligation on Parliament to facilitate public involvement, and that a failure to do so must result in constitutional invalidity. It is not sufficient for Parliament to simply allow the public to participate - it is, rather, under a positive duty 'to provide meaningful opportunities for public participation in the law-making process' and 'to take measures to ensure that people have the ability to take advantage of the opportunities provided'. ${ }^{6}$ Although Parliament has a discretion to determine the form that such opportunities for participation must take, the Constitutional Court has the power to test whether the steps taken by Parliament to facilitate public involvement are reasonable. What is reasonable depends on the context: sometimes it will suffice to invite the public to make written submissions, and at other times nothing short of public hearings will do. ${ }^{7}$ The following factors are relevant to the reasonableness inquiry:

'The nature and importance of the legislation and the intensity of its impact on the public are especially relevant. Reasonableness also requires that appropriate account be paid to practicalities such as time and expense, which relate to the efficiency of the law-making process. Yet the saving of money and time in itself does not justify inadequate opportunities for public involvement. In addition, in evaluating the reasonableness of Parliament's conduct, this Court will have regard to what Parliament itself considered to be appropriate public involvement in the light of the legislation's content, importance and urgency. Indeed, this Court will pay particular attention to what Parliament considers to be appropriate public involvement. ${ }^{8}$

The majority held that the National Council of Provinces (NCOP) had failed to meet its constitutional obligation in relation to two of the four Acts. These two Acts related to controversial matters of great public interest, namely the termination of pregnancies and traditional health practitioners. Moreover, the NCOP itself was of the view that it was desirable to

6 Doctors for Life, note 3, par. 129.

7 See Doctors for Life, note 3, par. 142.

8 Doctors for Life, note 3, par. 128. 
hold public hearings in relation to these two Acts. In view of these factors, the NCOP's failure to hold public hearings was unreasonable. The Court held that public hearings by the National Assembly (NA) were no substitute for public hearings by the NCOP and/or provincial legislatures: given the NCOP's constitutional mandate to represent the provinces in the national sphere, it could not evade its constitutional responsibility by relying on representations that had been received by the NA. ${ }^{9}$

Ngcobo J's judgment relied on a wide range of materials and arguments. He argued that the plain meaning of the words 'facilitation' and 'public involvement' used in s 72(1)(a) of the Constitution makes it clear that the legislature is under a positive obligation to take 'steps to ensure that the public participates in the legislative process' ${ }^{10}$ He further held that the obligation to facilitate public involvement gives effect to the right to political participation under international law, and must therefore be construed with reference to art 25 of the International Covenant on Civil and Political Rights (ICCPR), which states that '[e]very citizen shall have the right and opportunity' to political participation, read together with art 19 which guarantees right of freedom of expression. The Court interpreted these articles as recognising not only a positive right of citizens to political participation, but also a corresponding obligation on 'states to facilitate public participation in the conduct of public affairs by ensuring that this right can be realised'. ${ }^{11}$ In addition, Ngcobo J's judgment placed the constitutional commitment to democratic participation within the historical context of the apartheid system, which denied the majority a say in political life, and the anti-apartheid struggle, with its emphasis on people's power and community involvement. ${ }^{12} \mathrm{He}$ stated that 'the people of South Africa reserved for themselves part of the sovereign legislative authority that they otherwise delegated to the representative bodies they created'. ${ }^{13}$

By contrast, the minority rejected the idea that Parliament is constitutionally obliged to take reasonable steps to facilitate public involvement, and that a failure to do so must result in the invalidity of the legislation in question. Yacoob $\mathrm{J}$ in his dissenting judgment agreed that the constitutional vision of democracy includes both representative and participatory ele-

9 Doctors for Life, note 3, par. 151.

10 Doctors for Life, note 3, par. 120.

11 Doctors for Life, note 3, par. 92.

12 Doctors for Life, note 3, par. 111-112.

13 Doctors for Life, note 3, par. 110. 
ments, but largely confined the latter to voting and participation in the activities of political parties. ${ }^{14}$ In his view, neither the plain meaning of the words used in s 72(1)(a), nor the structure of the chapter on Parliament, supports the position taken by the majority. He argued that the word 'facilitate' implies a more lenient requirement than 'ensure' or 'require'; that the term 'public involvement' means something less than 'public participation'; that the word 'reasonable' is not used in the section; and that $\mathrm{s}$ 72(1)(a) does not form part of the Constitution's 'manner and form' requirements which prescribe particular legislative procedures. He rejected the majority's expansive reading of art 25 of the ICCPR, and placed the constitutional provisions relating to democracy within a different historical context. For Yacoob J, the primary historical wrong that the constitutional provisions on democracy aim to correct is not the absence of public participation in government processes during apartheid, but the exclusion of the majority of the population from the vote and from representation in Parliament. ${ }^{15}$ So viewed, when the Constitution proclaims that Parliament must ensure 'government by the people', it refers to their representation in Parliament, not to direct public involvement in government processes. ${ }^{16} \mathrm{In}$ the absence of a clear constitutional mandate, the judicial imposition of an enforceable obligation on Parliament to facilitate public involvement in all its processes, amounts to the usurpation of legislative power. It also constitutes 'an impermissible intrusion... on the value of the right to vote acquired through bitter struggle'. ${ }^{17}$

The majority and minority thus differed fundamentally in their understanding of democracy and of the judiciary's role in policing the democratic process. In the minority's view, the struggle for democracy in South Africa was primarily a struggle for representative democracy based on regular elections and universal adult suffrage. Likewise, the principal mechanism through which the Constitution attempts to secure government by the people is through the representation of their views in Parliament. Because of their democratic mandate, members of Parliament should not be held bound by vaguely defined standards of public participation, and the courts should be circumspect in interfering with Parliament's constitutional power to determine its own procedures. The majority judgment, on

14 Doctors for Life, note 3, par. 272, 276-281.

15 Doctors for Life, note 3, par. 294, with reference to s 42(3) of the Constitution.

16 Doctors for Life, note 3, par. 283.

17 Doctors for Life, note 3, par. 319. 
the other hand, resisted an interpretation that would relegate the participatory strands of the constitutional concept of democracy to a mere adjunct to the representative dimension. It described the representative and participatory elements of democracy as 'mutually supportive', ${ }^{18}$ and took the Constitution to envisage a dialogue between the people and their representatives which promotes the democratic values of openness, accountability and responsiveness, and bolsters the legitimacy of representative institutions. The majority acknowledged that the Court must respect Parliament's discretion in regulating its own processes, and deciding how to exercise its powers and give effect to its constitutional obligations. However, such deference does not amount to submission to the Legislature based on concerns of political sensitivity, and needs to be balanced against the right of the public to participate in public affairs. In their view, a reasonableness standard strikes an appropriate balance between these conflicting concerns. ${ }^{19}$

\section{Democracy and Civic Dignity}

The majority in Doctors for Life emphasised the close link between participatory democracy and the dignity of citizens. Ngcobo J stated that public participation 'enhances the civic dignity of those who participate by enabling their voices to be heard and taken account of' ${ }^{20}$ He further noted:

'All parties interested in legislation should feel that they have been given a real opportunity to have their say, that they are taken seriously as citizens and that their views matter and will receive due consideration at the moments when they could possibly influence decisions in a meaningful fashion. ${ }^{21}$

18 Doctors for Life, note 3, par. 115.

19 Doctors for Life, note 3, par. 122-124, 146.

20 Doctors for Life, note 3, par. 115.

21 Doctors for Life, note 3, par. 171. Sachs J similarly wrote in his concurring judgment: 'Minority groups should feel that even if their concerns are not fully represented, they continue to be part of the body politic with the full civic dignity that goes with citizenship in a constitutional democracy. Public involvement will also be of particular significance for members of groups that have been the victims of processes of historical silencing. It is constitutive of their dignity as citizens today that they not only have a chance to speak, but also enjoy the assurance they will be listened to. This would be of special relevance for those who may feel politically disadvantaged at present because they lack higher education, access to resources and strong political connections.' Par. 234. 
These statements suggest that civic dignity is enhanced when those affected by legislation are given the opportunity to raise their concerns and express their views. Dignity and democracy converge in their demand that citizens be heard, that they be given the chance to participate in public decision making and that they be treated as moral and political equals. By focusing on the intersection of these values, the Court moved away from a formal conception of democracy which stresses the identity of the people with their representatives, and embraced instead a deliberative and participatory understanding, which emphasises the need for ongoing consultation between MPs and the electorate. ${ }^{22}$ Rather than simply assuming that public representatives will govern in accordance with the wishes of the electorate, the majority conceives democracy as a communicative process 'in which every reasonable attempt is made to accommodate, or at least listen, to divergent views'. ${ }^{23}$ The judgment thus emphasises the plurality of the needs and viewpoints of the electorate, and the obligation of representatives to take them seriously.

But what is meant by 'civic dignity' and how is it related to human dignity? Whereas human dignity inheres in individuals by virtue of their humanity, civic dignity attaches to citizens and is grounded in their membership and participation in an 'interactive' community'. ${ }^{24}$ Brown argues that the civic dignity of the people is to be respected, because of the 'office' they hold as citizens. ${ }^{25}$ Civic dignity is rooted in the fact that the

22 Henk Botha, Representing the Poor: Law, Poverty and Democracy, Stellenbosch Law Review 22 (2011), p. 521.

23 Roux, note 4, ch. 10. p. 73.

24 Daly, note 5, p. 138. Jeremy Waldron, Dignity and Defamation: The Visibility of Hate, Harvard Law Review, 123 (2010), p. 1607 writes in the context of hate speech cases that there is a difference 'between the concern for personalized reputation in civil cases and a broader social concern for the fundamentals of anyone's reputation or civic dignity as a member of society in good standing'. Although civic dignity in many respects complement human dignity, both Hughes and Woolman warn that the dignity of citizens as the collective should not be conflated with dignified treatment owed to individuals. See Anne Hughes, Human Dignity and Fundamental Rights in South Africa and Ireland, Pretoria 2014, p. 93 and Stuart Woolman, Dignity, in: Stuart Woolman and Michael Bishop (eds.), Constitutional Law of South Africa, Cape Town 2007, ch. 36, p. 70. Civic dignity requires an objective approach, while the determination of whether or not someone was treated in a dignified manner has an element of subjectivity.

25 See Alex Brown, Hate Speech Law: A Philosophical Examination, New York 2015,142 . The idea that dignity considerations can be related to an 'office' is also 
roles and functions associated with the 'office' of citizenship 'are creations of the collective public, not the individual who occupies the role'. ${ }^{26}$ Civic dignity therefore has a relational and collective character, and refers to citizens' interactions within the public sphere. ${ }^{27}$ Ober explains the distinction as follows:

'Human dignity, as an inherent attribute of the individual, rests neither on personal nor on political relationships among people. Civic dignity stands in between these poles: It is predicated on a shared status of political equality among a body of citizens - a defined set of people who are jointly committed to the preservation of a public domain (a politeia, or res publica), but who are not social peers and who may have no personal ties with one another. ${ }^{28}$

Participation and the opportunity to be heard are vital elements of civic dignity. This was recognised in the Truth and Reconciliation Commission proceedings, where victims of political atrocities could be heard in a nonadversarial process aimed at 'the particularized restoration of their human

endorsed by James Gardner, The Dignity of Voters - A 'Dissent', University of Miami Law Review 64 (2010), p. 455, who states that '[v]oters may indeed possess some kind of dignity that is entitled to some manner of respect, but it is necessarily the dignity associated with a specific, contingent, socially constructed role'.

26 Gardner, note 25, p. 455 argues that the form and extent of civic dignity with which public participation is associated is activity rather than attribute based. Whereas human dignity is owed to every person, because he or she is a human being entitled to the same respect due to all other humans, civic dignity is collectively acknowledged and granted purely on the basis of citizenship. Gardner also explains that the 'dignity people possess as voters [or citizens] is not the dignity that they possess on account of being human. Whatever its virtues, [civic dignity as it relates to] democratic self-governance is not an aspect of intrinsic human dignity'. See also Brown, note 25, p. 142.

27 Woolman, note 24 , ch. 36, pp. 7 - 15 identifies five forms of dignity. These are: the recognition of the individual's inner worth (dignity 1), dignity as an entitlement to equal concern and equal respect (dignity 2), dignity as enabling the development of an individual's own humanity potential (dignity 3), dignity as recognition of people to legislate for themselves, i.e. self-governance (dignity 4), and dignity as attached to society as a collective (dignity 5). The last two forms (dignity 4 and dignity 5), best align with the idea of civic dignity as reflected in Doctors for Life. Susie Cowen, Can 'Dignity' Guide South Africa's Equality Jurisprudence?, South African Journal on Human Rights, 17 (2001), p. 58 also recognises the multi-form nature of dignity as a concept, namely the fact that it is useful to address constitutional issues at both a collective and individual level. See Hughes, note 24, p. 94.

28 Josiah Ober, Three Kinds of Dignity, http://athensdialogues.chs.harvard.edu/cgibin/WebObjects/athensdialogues.woa/wa/dist?dis=22 (last accessed on $31 \mathrm{March}$ 2015). 
and civil dignity' ${ }^{29}$ The civic dignity of victims was respected as part of the restoration process by acknowledging them not only as people with a story, but as people who deserved public recognition of their stories. Similarly, the majority in Doctors for Life acknowledged that if Parliament does not allow citizens sufficient opportunity to exercise their constitutional right to participate in the legislative process, it undermines their civic dignity by denying them the opportunity to be recognised as citizens capable of engaging in collective processes of self-government. ${ }^{30}$ The dignity of citizens precludes the state from treating them as mere objects of legislative and bureaucratic procedures, who are incapable of participating in the making of choices affecting the public. ${ }^{31}$ They are, rather to be treated as moral equals whose views must not only be heard, but must be listened to by public representatives. ${ }^{32}$ This does not mean that the legislature is bound to follow their opinions, but it must give them due consideration. ${ }^{33}$

Civic dignity denotes a status of equality: all citizens are afforded the same legal and social status, regardless of differences relating to race, ethnicity, gender or wealth. ${ }^{34}$ In the words of s 3(2)(a) of the Constitution: 'All citizens are equally entitled to the rights, privileges and benefits of citizenship.' This is reflected in the equality of the vote. As Sachs J held in August v Electoral Commission:

'The vote of each and every citizen is a badge of dignity and of personhood. Quite literally, it says that everybody counts. In a country of great disparities

29 Robert I Rotberg \& Dennis Thompson (eds.), Truth v Justice: The Morality of Truth Commissions, New Jersey 2000, p. 134.

30 See Doctors for Life, note 3, par. 115 (Ngcobo J) and par. 234-235 (Sachs J). See also Woolman, note 24, ch. 36, p.13; Michael Bishop, Vampire or Prince? The Listening Constitution and Merafong Demarcation Forum \& Others v President of the Republic of South Africa and Others, Constitutional Court Review 2 (2009), p. 323. Cf Gardner, note 25, p. 453; Metro Broadcasting, Inc v FCC 497 US 547 (1990) 604, dissenting judgment of O'Connor J.

31 Josiah Ober, Democracy's Dignity, American Political Science Review 106 (2012), p. 828 states that civic dignity requires citizens to be treated as choice making adults. He refers to this as the 'noninfantilization' principle.

32 Bishop, note 30, p. 323; Doctors for Life, note 3, para. 235 (Sachs J).

33 Bishop, note 30, p. 325 explains with reference to Democratic Alliance v Masondo 2003 (2) SA 413 (CC) that, although the majority decision may in the end trump public submissions, the latter must at least be granted the respect of consideration, as 'deliberation is central to democracy'. See also Roux, note 4, ch. 10, p. 68.

34 Brown, note 25, p. 142. 
of wealth and power it declares that whoever we are, whether rich or poor, exalted or disgraced, we all belong to the same democratic South African nation; that our destinies are intertwined in a single interactive polity'. ${ }^{35}$

But civic dignity, together with the closely related principle of political equality, demands more than that each adult citizen has the right to vote. It also presupposes that citizens have an equal chance to participate in public processes of democratic opinion- and will-formation. A situation where the rich and powerful are able to influence political decision making through means other than the ballot, would be contrary to the equal dignity of all citizens, if an opportunity to participate were not extended to all citizens. In his majority judgment in Doctors for Life, Ngcobo J stated that public participation, 'because of its open and public character acts as a counterweight to secret lobbying and influence peddling. Participatory democracy is of special importance to those who are relatively disempowered in a country like ours where great disparities of wealth and influence exist'. ${ }^{36}$

Put differently, representative democracy is associated with universal citizenship, which extends political rights to all citizens, regardless of their standing. At the same time, however, the transfer of legislative power to an elite group of citizens who represent the interests of their constituents potentially detracts from the principle of equal citizenship. Drawing on Machiavelli's political theory, John McCormick warns against the danger of an unchallenged elite group of representatives wielding political power through the 'narrowing of popular participation' 37 to just a right to vote. ${ }^{38}$ McCormick emphasises the need for broad democratic participation as counter to the risk of a representative faction and of political inequality.

\section{Judicial Decisions after Doctors for Life}

Following Doctors for Life, the Constitutional Court considered the legislature's obligation to facilitate public involvement in a number of other

351999 (3) SA 1 (CC) par. 17.

36 Doctors for Life, note 3, par. 115.

37 John P McCormick, Machiavellian Democracy, New York 2011, p. 142.

38 McCormick, note 37, p. 142 argues, with reference to Machiavelli's political theory, that 'the sharp curtailing of popular participation ... [serves] only the interests of the elites consequently empowered to act on behalf of the people'. 
cases. Matatiele II, ${ }^{39}$ a case decided a day after Doctors for Life, concerned a constitutional amendment designed to abolish cross-boundary municipalities, in terms of which the area of Matatiele was transferred from the province of KwaZulu-Natal to the province of the Eastern Cape. Ngcobo J, in another majority judgment, found that the Provincial Legislature of KwaZulu-Natal had failed to take reasonable steps to facilitate public involvement prior to its decision to support the constitutional amendment. ${ }^{40}$ The majority, in evaluating whether the degree of participation facilitated was sufficient, took into consideration the impact of the legislation on the people of Matatiele. Given their emotional attachment to KwaZulu-Natal, the potential implications of their relocation for service delivery, and the fact that the legislation's 'direct and profound impact' was felt by 'a discrete and identifiable section of the population', ${ }^{41}$ namely the people of Matatiele, the legislation could not be passed without proper consultation. It held:

'The more discrete and identifiable the potentially affected section of the population, and the more intense the possible effect on their interests, the more reasonable it would be to expect the legislature to be astute to ensure that the potentially affected section of the population is given a reasonable opportunity to have a say. ${ }^{42}$

The cases that followed Matatiele II similarly concerned the abolition of cross-boundary municipalities and changes to provincial boundaries. In Merafong, ${ }^{43}$ a challenge was brought against the transfer of Merafong Municipality from Gauteng to the North West Province. The Gauteng Provincial Legislature had held public hearings, during which members of the community clearly expressed their opposition to the municipality's relocation. These views were taken into account: in terms of the negotiating mandate adopted by the Gauteng Provincial Legislature, it would support the amendment subject to the condition that Merafong had to remain part of Gauteng. However, it subsequently reversed its original mandate and

39 Matatiele Municipality \& Others v President of the Republic of South Africa \& Others 2007 (1) BCLR 47 (CC). Hereafter 'Matatiele II'.

40 Yacoob J again dissented (with the concurrence of Van der Westhuizen J) in Matatiele II, note 39, based on the same reasoning as provided in Doctors for Life.

41 Matatiele II, note 39, par. 79.

42 Matatiele II, note 39, par. 67.

43 Merafong Demarcation Forum \& Others v President of the RSA \& Others 2008 (10) BCLR 969 (CC). Hereafter, 'Merafong'. 
the Gauteng delegation voted in support of the Bill in the NCOP. The Court, this time with Van der Westhuizen J writing for the majority, found that although the affected group of citizens were not informed of the change in the decision of the Gauteng delegation, their participation was still meaningful. The majority therefore ruled that the obligation to facilitate public participation in the given context had been met. It acknowledged that '[p]ublic involvement cannot be meaningful in the absence of a willingness to consider all views expressed by the public'. ${ }^{44}$ Van der Westhuizen $\mathrm{J}$ nevertheless reasoned that, even though the provincial legislature's failure to inform the people of their about-turn, was disrespectful '[f]rom the perspective of respectful dialogue and the accountability of political representatives', ${ }^{45}$ there was nothing that forced the Legislature to submit to the views expressed during public hearings. ${ }^{46}$ Accordingly, the failure to report back to the Merafong community was not so unreasonable that it had to result in the invalidity of the constitutional amendment. ${ }^{47}$

Even though Merafong raised more complex issues than Doctors for Life or Matatiele II, it could nevertheless be asked whether the majority judgment does not detract from the promise of the Constitutional Court's earlier jurisprudence on participatory democracy. As Budlender comments, the majority in 'Merafong notably de-emphasised the participatory element of our democracy in determining the margins of what constituted reasonable facilitation of public involvement in the circumstances of this case'. ${ }^{48}$ The majority's finding that it was not necessary to revert back to the community, and that it was in any event unlikely that another round of public consultation would have made a difference to the legislature's position, ${ }^{49}$ is particularly problematic in view of the link between public participation and civic dignity. As Sachs J pointed out in his dissent, the Court's earlier jurisprudence had emphasised the idea of a dialogue between the people and their elected representatives. He added: '[i]n some ways an interrupted dialogue, when expectations of candour and open-

44 Merafong, note 43, par. 51.

45 Merafong, note 43, par. 55.

46 See Botha, note 22, p. 528 with reference to Merafong, note 43, par. 50.

47 Merafong, note 43, par. 56.

48 Steven Budlender, National Legislative Authority, in: Stuart Woolman and Michael Bishop (eds.), Constitutional Law of South Africa, Cape Town 2007, ch. 17, p. 78.

49 Merafong, note 43, par. 59. 
dealing have been established and certain ambiguous commitments have been made, can be more disruptive of a relationship than silence from the start might have been'. ${ }^{50}$ In his view, the failure of communication on the part of the legislature diminished the civic dignity of the community of Merafong, undermined the legitimacy of the democratic process, gave rise to the perception that public involvement had been a sham, and subverted attempts to establish relations of trust between the people and their representatives. ${ }^{51}$

Following Merafong, the Constitutional Court in Poverty Alleviation Network ${ }^{52}$ was presented with another opportunity to return to its Doctors for Life roots, as the residents of Matatiele challenged the validity of a second constitutional amendment aimed at effecting the relocation of the municipality from KwaZulu-Natal to the Eastern Cape. ${ }^{53}$ This time the applicants did not argue non-facilitation, as hearings had been held at which the community had the opportunity to express their grievances. Rather, they argued that public participation was a sham, as the legislature's position was politically dictated and predetermined. Nkabinde $\mathrm{J}$ on behalf of a unanimous court dismissed the application. She held that, even though the legislature must consider the public's views, it need not be swayed by them. The Court further held that it was not appropriate for the Court to inquire into the legislature's motives, and that it can only ask whether its decisions are rational. ${ }^{54}$ It found that the legislation was rationally connected to the abolition of cross-boundary municipalities, which is a legitimate government objective, and that it was accordingly valid.

The Moutse case ${ }^{55}$ also concerned the alteration of provincial boundaries, as the applicants challenged the relocation of certain areas from the province of Mpumalanga to the province of Limpopo. A public hearing was held, but the applicants argued that adequate notice of the hearing was not given and that the provincial legislature was not properly informed of the community's views, as the report provided to it was very skeletal. The

50 Merafong, note 43, par. 291.

51 Merafong, note 43, par. 292, 298.

52 Poverty Alleviation Network \& Others v President of the Republic of SA 2010 (6) BCLR 520 (CC). Hereafter, 'Poverty Alleviation Network'. See Budlender, note 48 , ch. 17 , p. 64.

53 See Budlender, note 48, ch. 17, p. 75.

54 Poverty Alleviation Network, note 52, par. 73.

55 Moutse Demarcation Forum and Others $v$ President of the Republic of South Africa and Others 2011 (11) BCLR 1158 (CC). Hereafter, 'Moutse'. 
Court rejected these contentions. It held inter alia that a court could not 'pronounce on the adequacy of the information at the disposal of a deliberative body such as the legislature before it makes a decision' or 'prescribe to the Legislature what a report to it should contain'. ${ }^{56}$

In its reasoning in Merafong, Poverty Alleviation Network and Moutse, the Constitutional Court watered down the strong conception of participatory democracy articulated in Doctors for Life and Matatiele, compromised on the rigour of the reasonableness test developed in those cases and deferred more readily to the Legislature. The Court thus opened the door to the representative faction risk of an elite speaking on behalf of citizens after hearing them, but not really listening to them in a respectful manner. It is arguable that this judicial stance has negatively impacted on the level of confidence citizens have in Parliament's participation programmes, resulting in an intensification of radical, citizen-driven forms of participation. ${ }^{57}$

If the link between public participation and civic dignity is downplayed, the only avenues left to the Court in cases like Merafong, Poverty Alleviation Network and Moutse are to challenge the rationality of the Legislature's decision or to question whether it really considered the public's submissions with an open mind. ${ }^{58} \mathrm{~A}$ rationality challenge is unlikely to succeed, as it is a relatively weak form of review, and as the Court has made it clear that it will not inquire into the rationality of the procedures used by Parliament. ${ }^{59}$ In the absence of 'very strong evidence', ${ }^{60}$ it is also unlikely that a court will find that Parliament has failed to consider the public's submissions, particularly since the Court has expressly dissociated rationality review from a consideration of the motives of the Legislature. ${ }^{61}$

56 Moutse, note 55, par. 80.

57 In the aftermath of the Constitutional Court's judgment in Merafong, protests - including violent ones - continued amongst the Merafong community. The new ANC leadership which was elected at the party's National Conference in Polokwane in December 2007 visited the area and resolved to reverse the incorporation of Merafong into the North West Province. This was accomplished through the enactment of the Constitution Sixteenth Amendment Act of 2009.

58 See Budlender, note 48, ch. 17, p.79.

59 Poverty Alleviation Network, note 52, par. 68.

60 Budlender, note 48, ch. 17, p. 79.

61 Poverty Alleviation Network, note 52, par. 73. 


\section{E. Conclusion}

The Constitution envisages a form of democracy which is both representative and participatory in nature. ${ }^{62}$ As the majority declared in Doctors for Life, 'the representative and participatory elements of our democracy should not be seen as being in tension with each other ... [but rather] as mutually supportive'. ${ }^{63}$ On this vision, democracy requires mechanisms which guarantee the right of citizens to participate in the political process, in addition to strong representative institutions. This is secured not only through the right to vote for elected representatives, but also through the right to petition Parliament, ${ }^{64}$ lobby representatives to table private member bills, ${ }^{65}$ and make representations to them when processing legislation. ${ }^{66}$ Representation and participation are therefore seen as two sides of the same coin. Both help to ensure that government is in accordance with

62 Ober, note 31, 827 explains that '[i]n a democracy meeting the minimal standard, an extensive citizenry (We, the people, ho demos) has authority over first- and second-order rules (legislation and procedure); citizens have secure political rights (to speech, assembly, vote, office); officials are held to account by citizens'.

63 Doctors for Life, note 3, par. 115.

64 See section 17, read with section 56(d) of the Constitution. Rules $309-315$ and $229-236$ of the Rules of the NA and the Rules of the NCOP respectively give effect to the right of citizens to petition Parliament.

65 See Oriani-Ambrosini, MP v Sisulu, MP Speaker of the National Assembly 2013 (1) BCLR 14 (CC) and the revised rules 234 - 236 of the Rules of the National Assembly. Parliament has subsequent to this judgment set up a dedicated Legislative Drafting Unit within the Constitutional \& Legal Services Office to assist members with the drafting of private member bills. For this purpose, the NA through a resolution adopted interim rules to be followed in this regard.

66 In practice, such facilitation usually takes the form of an advertised call for written submissions, followed by public hearings if further consideration of the written submissions so require. In practice, provincial legislatures also call for public participation and comment to inform the voting on section 76 bills. In such instances the section 118(1)(a) obligation the Constitution places on provinces to 'facilitate public participation' becomes of great importance, as that informs the mandates with which they vote in the NCOP. For the different types of mandates see the Mandating Procedures of Provinces Act 52 of 2008. It must also be noted that Rule 168 of the Rules of the NCOP does allow for the relevant select committee processing a bill (and liaising with provinces in a section 76 bill context) may nevertheless direct that such a bill be published in the Gazette and invite the public to make representations. In support of the principle of public participation, the NCOP also annually facilitates an oversight drive called 'Taking Parliament to the People', where the members engage various communities directly. 
the will of the people, and both are grounded in respect for the dignity of citizens and the 'office' they hold.

However, the judgments in Merafong, Poverty Alleviation Network and Moutse reveal the precarious nature of the balance struck in Doctors for Life and Matatiele II between representative and participatory democracy. In these three cases, public hearings were held, but the relevant laws and constitutional amendments were nevertheless pushed through, notwithstanding strong resistance on the part of the affected communities. In each of these cases, the Constitutional Court held that the legislatures complied with the constitutional obligation to facilitate public involvement, despite allegations that they did not truly consider the submissions of the public. On one view, this is unobjectionable, as legislatures are not bound by the views of the public, and as courts should be careful not to substitute their own views for those of the legislature. However, on another, it is problematic. Given the powerful position of political parties in South Africa's list system of proportional representation, and widespread poverty and inequality, courts have a particular responsibility to uphold the constitutional values of democracy and civic dignity in the face of any apparent attempts to side-line the citizenry and monopolise public power. ${ }^{67}$

The deferential tone adopted in Merafong, Poverty Alleviation Network and Moutse is worrying, as it represents a step away from the articulation of democracy and civic dignity in Doctors for Life. It also backtracks from the robust understanding of separation of powers embraced in that case, in terms of which judicial review does not necessarily detract from democracy, but sometimes enhances it. ${ }^{68}$ These judgments, in neglecting to engage with civic dignity as the basis for meaningful public participation in the legislative process, are too quick to assume that public representatives will always govern in accordance with the wishes of the electorate. They thus undermine the balance between representative and participatory democracy, and risk leaving citizens at the mercy of an unchecked representative elite.

67 See Sujit Choudhry, 'He Had a Mandate': The South African Constitutional Court and the African National Congress in a Dominant Party Democracy, Constitutional Court Review, 2 (2009), p. 1.

68 See Roux, note 4, ch. 10, p. 20. 